\title{
Behavior of Tourists and the Future of Middle Class Tourism: A Phenomenological Study of Sunan Giri and Sunan Drajat Tombs
}

\section{Fahmi Prihantoro ${ }^{1}$ and Ghifari Yuristiadhi²}

${ }^{1}$ Faculty of Arts and Humanities, Universitas Gadjah Mada, Jl. Nusantara 1, Bulaksumur Yogyakarta 55281, Indonesia

${ }^{2}$ Vocational College, Universitas Gadjah Mada, SV UGM Building, Sekip Unit 1, Caturtunggal, Sleman, Yogyakarta 55281, Indonesia

\section{Abstract}

The study using archeology and tourism approachs, restricts to two tombs of Wali Songo: Sunan Giri in Gresik and Sunan Drajat in Lamongan. Three things analized are: i) how behaviors of pilgrims, who mostly middle class, which threaten sustainability of this heritage site in the future, ii) to what extend the impact of behaviors of pilgrims

Corresponding Author: Fahmi Prihantoro fahmi_p@ugm.ac.id

Received: 2 April 2018 Accepted: 17 April 2018 Published: 23 May 2018

Publishing services provided by Knowledge

(c) Fahmi Prihantoro and Ghifari Yuristiadhi. This article is distributed under the terms of the Creative Commons

Attribution License, which permits unrestricted use and redistribution provided that the original author and source are credited.

Selection and Peer-review under the responsibility of the 1st ICSEAS 2016 Conference Committee. to condition of cultural heritage there, iii) The ideal cultural heritage management that can be applied there. Data of this research collected by observation, interviews and secondary resources. This study results: Activities that tourist do there are tombs pilgrim, salat, iktikaf, and attending special ritual event. The duration of tomb pilgrim activity is different. Pilgrims perform various activities such as sitting against a headstone, allow their children to sit on top of the headstone, touching old gate, and put their footwear on tombs; Pilgrims activity caused the damages at the Sunan Giri on Courtyard II, Paduraksa Gate on courtyard III, fences tombs that utilized a place to put footwear, and the tombs in the courtyard I. While at the grave of Sunan Drajat, visitor activities caused the damage at courtyard III, especially in the gate and grave around main hall of Sunan Drajat tombs; The Ideal cultural heritage management in there for its sustainable according Law No. 11 Year 2010 is in three ways: i) protection, ii) development, and iii) utilization. This study is expected to be considered stakeholders in taking care of cultural heritage policies in Wali Songo complexes, especially concerning tourist behavior.

Keywords: Phenomenological research, The middle class, The tombs of Sunan Giri, The tombs of Sunan Muria, Tourist behavior. 


\section{Introduction}

Wali Songo tombs complex as religious heritage site is one of considerable archaeological wealth found in many regions of Indonesia. Exclude Wali Songo tombs, the king and the royal family graveyard as well as historic mosques that still associated with the spread of Islam in Indonesia are another example of cultural heritage site in Indonesia. One of the characteristics of the Wali Songo tombs complex as a tourist destination is it visited by many people (mass tourism phenomenon), especially for the sake of pilgrimage. The Wali Songo tombs complex is mainly located in the northern coast of Java. For Javanese people, especially the middle class, Wali Songo has a great charisma. So, for them, to visit the tombs of Wali Songo is a part of the necessity to have the blessing.

The existence of the tombs complex which part of the cultural heritage is certainly significance for the development of history, knowledge, and the national identity as mentioned in Law No. 11 Year 2010 on Cultural Heritage [1]. However, in its development, along with advances of tourism industry that allows people to easily access a variety of cultural heritage for tourism purposes, especially in the Wali Songo tombs complex for pilgrimage, it will be more threatening the existence of the tombs complex as a cultural heritage site.

Chambert-Loir and Guillot wrote comprehensively that community factors on the teaching of the congregation, prompted a wave of pilgrimage on the tombs of Wali Songo in Indonesia [2]. Pilgrimage tourism is one of several tourist activities definitely had a positive impact on the development of tourism in a region [3-5]. A wave of pilgrimages as never diminished over the years due to increasing levels of economy and ease of access to go to a tourist destination as well as access to information on the tourist destinations. It can be seen from the number of tourist that visiting several destinations pilgrimage tourism in Indonesia.

Two of Wali Songo tombs complexes in northern coast of Java are the tombs complex of Sunan Drajat and Sunan Giri, it is located in the district of Lamongan and Gresik, East Java Province. Both sites are visited by many pilgrims every day. On weekends and during vacation season, the number of pilgrims will be more than usual. Some damage that has occurred and the threat of damage is caused by the visitor's activity, the activity of the traders who sell around tombs, or by natural factors.

Compared with other regions such as Cirebon (Sunan Gunungjati tombs) and Kudus (Sunan Kudus and Muria tombs), tombs complex of Sunan Giri in Gresik and Sunan Drajat in Lamongan face the greater damage. Based on a survey on May 2014, the physical 
destruction of tombs complexes was on the ornamental of tomb's cupola and the gate of Sunan Giri. While on of Sunan Drajat tombs, physical damage was on the gates and there are no sufficient conservation efforts. There is also the addition of additional facilities for visitors who are not in accordance with the principle of conservation principal.

Characters of mass and less-awareness to cultural heritage around them that owned by tourists in the tombs complex of Sunan Giri and Sunan Drajat would threaten the sustainability of the tourist destinations in the future. These two characters (mass and less-awareness), added with limited budget brought by tourists, are complement with the character model of third world tourism as Gladstone termed [6]. Thus, pilgrimage tourism can be categorized into a model of third world tourism. However, authors want to use another term which is middle-class tourism because the term is more polite and does not impressed discredit. So, the term of middle-class that mentioned above is different than what H.W Dick and Robert W. Hefner mentioned. According H.W. Dick middle-class that a crucial new element in contemporary Indonesia is the civil servants and intelligensia who were the product of liberalized higher education in the late colonial period and, in the other hand, to the much older groups of muslim and chinese traders [7]. While according to Hefner, middle-class is taking shape even as the gap between rich and poor increased [8]

Activities of pilgrimage tourism undertaken by pilgrims at the tombs of Wali Songo that intensively performed and accompanied by behavioral pilgrims that less concerned over the preservation of cultural heritage threatened the sustainability of the cultural heritage site in Sunan Giri and Sunan Drajat tombs complexes. While research questions of this research are how behaviors of pilgrims, who mostly middle class, in Sunan Giri and Sunan Drajat which threaten sustainability of this heritage site in the future? To what extend the impact of behaviors of pilgrims to condition of cultural heritage site there? What is the ideal cultural heritage management that can be applied in Sunan Giri and Sunan Drajat tombs complexes?

The benefit gained from this research is description of the current condition of the religious heritage site in Sunan Giri and Sunan Drajat tombs complexes. This can be a subject of study for Cultural Heritage Preservation Agency (BPCB) East Java in their policy in order to preserve cultural heritage in East Java.

This research aims to identify the behaviors of pilgrims, who mostly middle class, in Sunan Giri and Sunan Drajat which threaten sustainability of this heritage site in the future; to identify the impact of behaviors of pilgrims to the condition of the cultural 
heritage there; and to formulate the ideal cultural heritage management that can be applied in Sunan Giri and Sunan Drajat tombs complexes.

Some models of cultural heritage management in Indonesia has been developed by several researchers in their research. The concept of cultural heritage management with environmental approach in Bali has been carried out by Wardi [9]. As known, in Bali's cultural heritage is largely a religious cultural heritage, so it is fair if the Hindu concept orientations on to protect the environment into the management system approach of heritage buildings there [9].

The next is cultural heritage management models through community participation approach. This model emphasizes the active participation of communities in managing cultural heritage, especially the urban cultural heritage. Titik $S$ take Old City of Semarang to become her case study. This model was chosen because it is basically the people also have a cultural heritage to be around the environment. It is expected by the community management model is more sustainable because it involves the community as part of the owners of cultural heritage [10].

Other management model that can be applied is the approach of legislation (laws). This management model tested application in Region Heritage of Kotagede. The emphasis of this management model is government policies that exist as a reference for managing cultural heritage [11].

Model of local wisdom in the temple management efforts can be an alternative to be applied. Each of cultural heritage has the potential of local knowledge that could be developed as a tourist attraction. The existence of such wisdom, for example ruwaton, could have an impact straight secure cultural heritage by the community as the owner of such wisdom. Some characters temple that has some unique form of local wisdom (ruwaton) especially for the sake of tourism. Of course, the application of this management model depends on the condition of the cultural heritage whether there is local knowledge that could be developed for tourism [12].

According Ichwan, the archaeological resource management can also be used for the benefit of religious tourism. An example is the tombs of Wali Songo. This could be an option because the characteristics of the tombs complex of Sunan is sacred and is still used today as initial function (living monument), so that the necessary efforts to use according to the nature of the archaeological resource is that management need to involve the government, civil society, and academia [13].

Based on the literature review above, interesting to look at the tombs complex cases Wali Songo as a sacred religious heritage site and the presence of quite a lot of visitors so it is necessary to guarantee its sustainability management efforts. 
Cultural heritage sites have the potential as knowledge, history, a cultural identity, and can also be used as the interests of the present [14]. Religious heritage site is one of the objects in the category of cultural tourism which can be used for special interests, such as tourism. To preserve the cultural heritage such as this, it is necessary to include the public participation for the sustainability of the place [15]. On the other hand, tourism and industrial development activities often threaten the destruction of cultural heritage [16].

Management of cultural heritage sites should have the concepts and strategies in order to realize the essence of the management of cultural heritage. The concept of management of cultural heritage in accordance with Pearson and Sullivan are: i) identification and documentation of cultural heritage and the region (the site), ii) assessment importance of cultural heritage, iii) planning strategy based on important values that are tailored to the principles of conservation, iv) planning and implementation of policies, v) evaluation and oversight [17].

Conservation of cultural heritage buildings into a single entity with the management of cultural heritage is the responsibility of society on an ongoing basis. According to John Earl, there are three fundamental problems of the background for the conservation of cultural heritage, namely i) motive, related to why we need to preserve ii) monument, with regard to what objects will we preserve, and iii) the manner and means with regard to how should do so [18].

Preservation activities as listed in the Burra Charter provides some limitation constraints, namely: i) maintenance, is the protection continuously on the materials and layout of a place; ii) preservation, is to keep the material in its existing state and slow down the damage; iii) restoration, is to restore the existing fabric of the original state by removing accretions or mimic the components are existing without the use of new materials; iv) reconstruction or restoration, is to restore cultural heritage in its original state to use new materials as component; v) adaptation, is modifying a place to suit the existing use or utilization the proposed; vi) utilization, is a place functions, including activities and activities that may be carried out in a proficiency level. Good utilization is a use which respects the cultural significance, does not cause negative impacts that threaten damage.

In this study that use archeology and tourism approach, data collected by library research, field surveys and interviews with stakeholders from the tombs complexes of Sunan Giri and Sunan Drajat. This is an inductive research method using descriptive approach that explains various phenomena described in the field and reviewed the literature to be analyzed using the concept of management of cultural heritage that 
has been formulated in the basic theory. Approach to the concept of conservation of cultural heritage (motive, monument, manner, and means) and community participation is also used as the basis management strategies making. From this analysis will produce conclusions that the answer to the problems.

\section{Research Objects Overview}

\subsection{Tombs complex of Sunan Giri}

Sunan Giri is one propagator of Islam in Java. Born in Blambangan 1422 AD of couples Maulana Ishaq and Dewi Sekardadung, the small name of Sunan Giri is Raden Paku or Jaka Samudra. After studying in Ampel Denta of Sunan Ampel who his uncle is, Sunan Giri then selected the area of Giri that is now preaching administratively Kebomas, District of Gresik, East Java, Indonesia until then establish the Kingdom of Giri Kedaton and occupied the throne since 1487 until his death in 1506 [19].

The Sunan Giri tombs complex is located in Giri located in the District Kebomas, Gresik, East Java Province, Indonesia. Geographically Gresik located at position $112^{\circ}$ $24^{\prime} 24^{\prime \prime}$ to $112^{\circ} 38^{\prime}$ east longitude and 6 $6^{\circ} 0^{\prime} 55^{\prime \prime}$ south latitude with an area of 1191.25 $\mathrm{km}^{2}$.

Gresik society culturally very thick with Islamic values. These values have been taken long ago by propagator of Islam, one of which is Sunan Giri, one of Wali Songo. Various Islamic tradition performed in the tombs complex of Sunan Giri, i.e. Haul Akbar (Great ceremony of Sunan Giri dead date), Malam Selawe (The $25^{\text {th }}$ night) tradition and Lelang Bandeng tradition.

Sunan Giri tombs complex is divided into three courtyards, stretched from north to south. Sunan Giri landscape tombs complex in the form of a staircase getting to the north (геar) higher. The steps also serve to sharing courtyard marked with a gate and talud every courtyard limit.

The first courtyard is the bottom courtyard on the tombs complex, but the land position is higher than the land in the south side. The driveway to the courtyard I marked with stairs and gate briefly with dragon statue on both sides. It is Candrasengkala that written "Naga Loro Warnaning Podo" = 1428 çaka (1506 AD).

The first courtyard is a courtyard of the most comprehensive and unbiased tombs that set irregular. On the first courtyard, there are also two pieces cupola located on the right (east) and left (west) path that connects the gate to the courtyard I and courtyard II. Both cupola has a shelf with a height of $0.15 \mathrm{~m}$, a pyramid-shaped roofs 
a

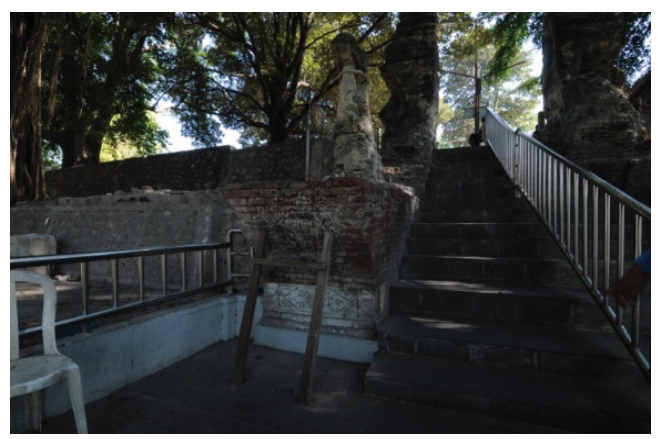

b

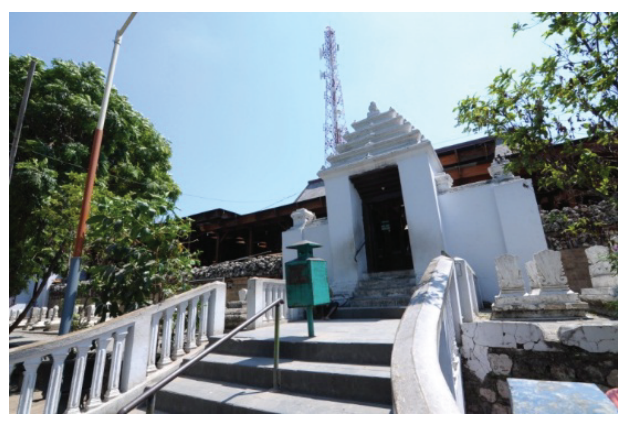

Figure 1: (a) Gate on Courtyard I of Sunan Giri Tombs, (b) Gate on Courtyard II of Sunan Giri Tombs (Photo: Windu Karsa).

cupola supported by four pillars. In the east, there is the tombs of the cupola Panembahan Tamengrogo while in the West there is the tombs of the cupola Panembahan Sontoputro.

Courtyard II is located in the north of the first courtyard and the location is higher compared with the courtyards I. On courtyard II marked by a minute and a stair gate. On courtyard II is divided into two terraces terrace $A$ and $B$. The location of the terrace $B$ higher than $A$ terrace and there is no barrier between the two terraces.

Spacious yard II is narrower than the first courtyard, the second courtyard there is also a tomb which was located not regularly shown on courtyard I. On courtyard II on the terrace and there is a path to westward linking the tombs complex with the tombs of Sunan Giri Prapen.

Courtyard III is located on the highest terrace and has a perimeter fence decorated rocks. On the third courtyard, there are two gate Paduraksa (Paduraksa A and Padurakso B). Paduraksa A gate is symmetrical with Gapura Bentar courtyard II, while the gate Paduraksa $B$ on the east side of the courtyard III.

A Poduraksa gate has a five storey roof with artefact ornate at each corner. Padurakso of gate B has a smaller size than the Paduraksa A. The function of Paduraksa B is to link courtyards with a grand mosque which is located in the east courtyard III.

According to Hartono, on courtyard III which is the main tombs complex there are five pieces of the cupola. Meanwhile, according to current data plan that is in the office complex of the tombs of Sunan Giri there are only four pieces of the cupola [20]. To simplify the explanation of the cupola on courtyard III of this, use Arabic numerals to refer to the cupola.

Cupola I is the greatest cupola containing 23 tombs of the students and relatives of Sunan Giri. The layout of the cupola I is in the northern fence of rocks, next to the 
west. Cupola I shape is square without walls, but at this time of the cupola is not there. Cupola II is located right in the north cupola I with a rectangular floor plan that extends west-east with the wall in the west, north, and east.

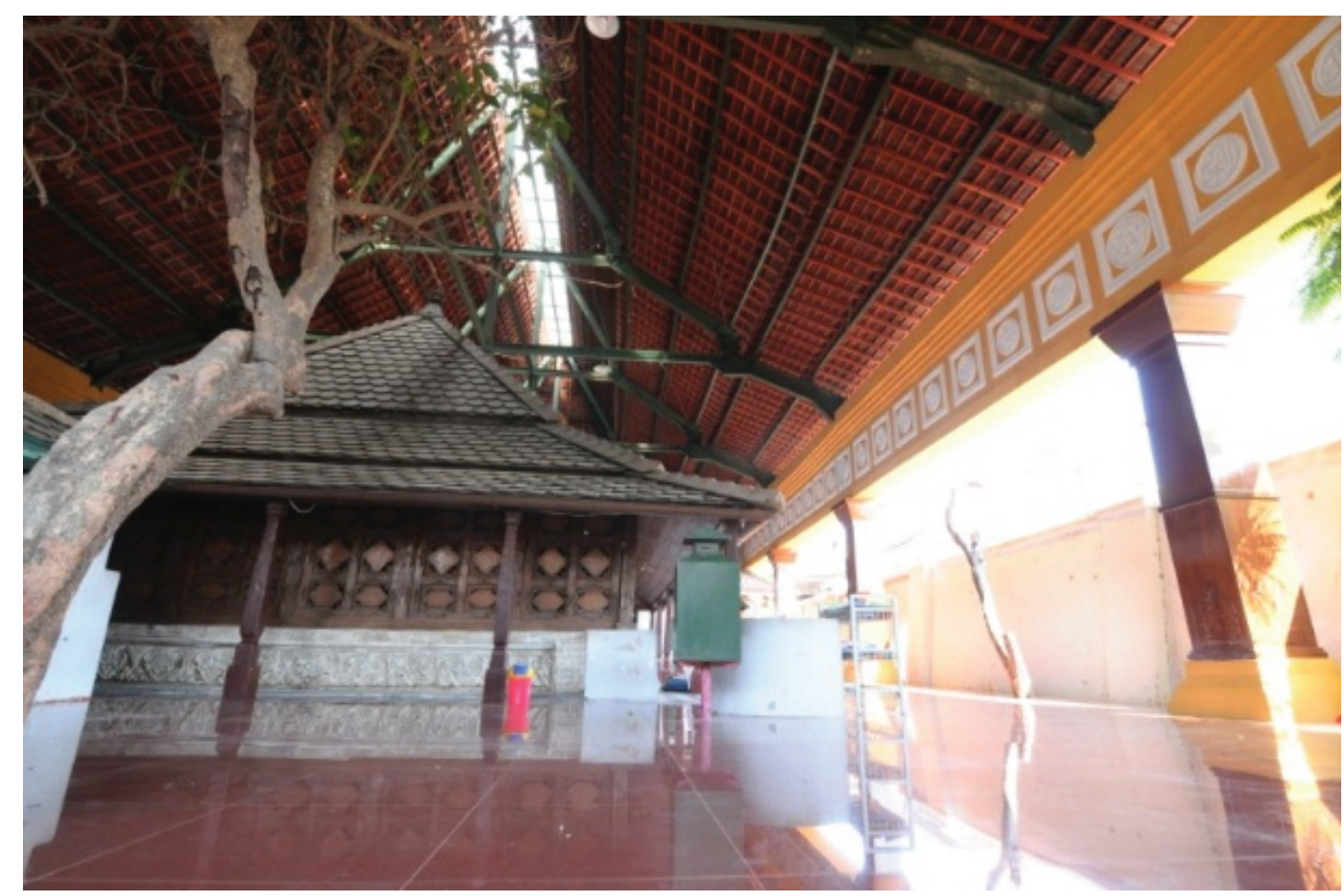

Figure 2: Main cupola of Sunan Giri Tombs (Photo: Windu Karsa).

In the cupola II, there are four tombs that are on a raised floor that is: Nyai Ageng Sawo tombs, the tombs of Sunan Kulon, the tombs of Prince Kidul, Central Sunan tombs. In addition to the tombs will be found two other tombs on different floors, i.e. Sunan Dalem tombs and the other tombs that don't have any identity.

Cupola III located on the east cupola II and housed rectangular. Whole sides have wall entrance from the south, the walls are carved with motifs of tendrils. In the cupola III there are two rooms. This cupola sized $8.80 \mathrm{~m} \times 8.80 \mathrm{~m}$.

Cupola IV is located at south part of cupola III, the cupola IV has a rectangular floor plan without walls. Inside the cupola IV there are two tombs is the tombs of Sunan Sedo ing Margi and his wife. Cupola V is located on the eastern of cupola III with a rectangular floor plan without walls. Inside there is a cupola $V$, five pieces graves of relatives Sunan Giri. 


\subsection{Tombs complex of Sunan Drajat}

The tombs complex of Sunan Drajat is located in the village Drajat, District Paciran, Lamongan, East Java, Indonesia. The complex stretches grave of Sunan Drajat southnorth and is divided into three courtyards increasingly backward (north) higher. Inside the complex there are two courtyards that are restricted by a fence of wood with a pitcher-shaped entrance Tinandu. According Setiyadi (cemetery caretaker) the possibility of both courtyards are additional courtyards built after the earthquake in 1950.

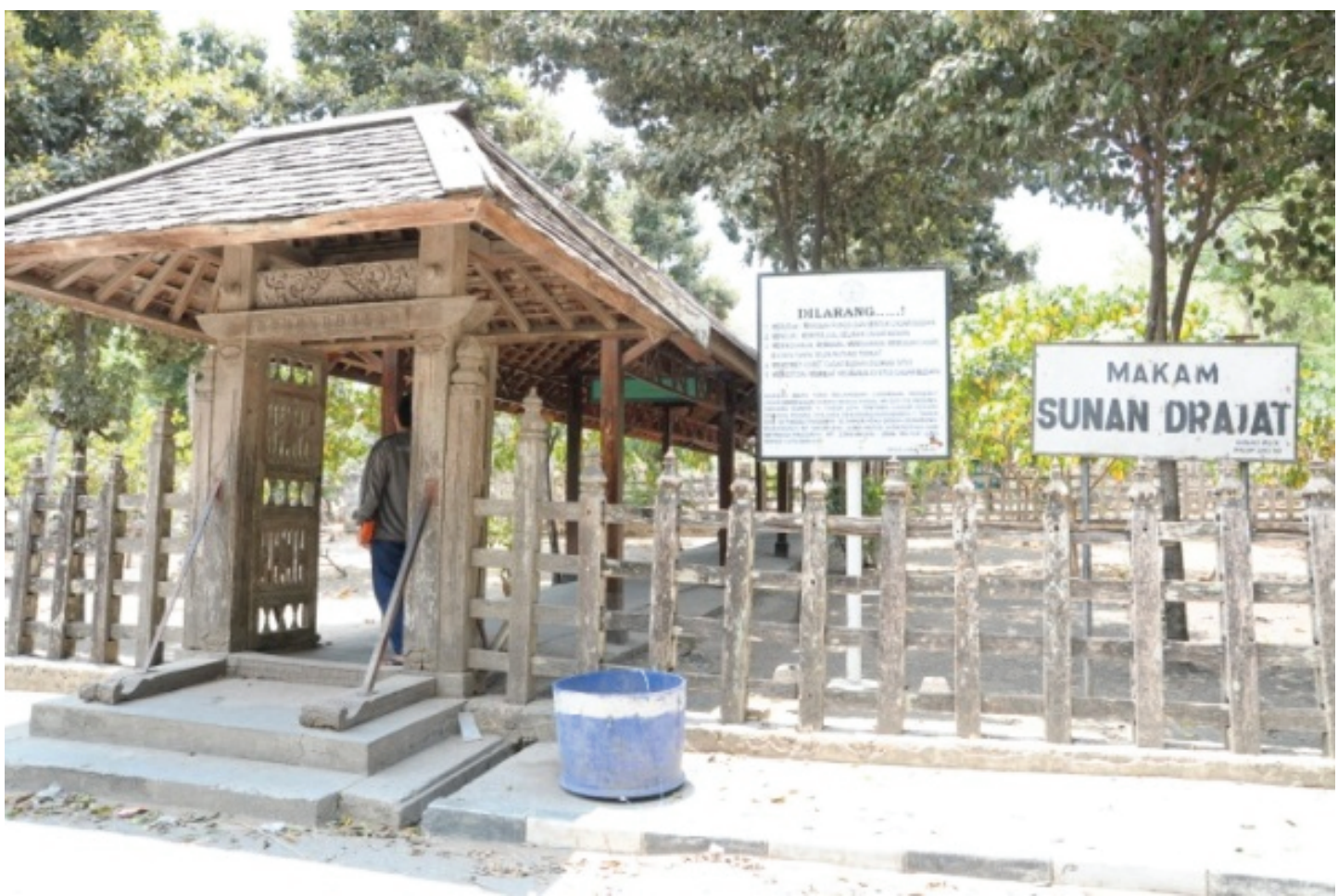

Figure 3: Complex gate of Sunan Drajat tombs (Photo: Windu Karsa).

Courtyard I bounded by a fence of white stone with the entrance in the form of white stone steps, but at this time has been cemented. At the entrance courtyard I had not found the gate because it was damaged by an earthquake in 1950 . On the first courtyard there are the tombs which have an irregular pattern, other than in the east road that connects courtyard 1 to courtyard II there is long marquee called Rante.

Weather II has a layout that is higher than I. Moreover, courtyard II marked with symmetrical entrance to the courtyard entrance I, courtyard II has a perimeter fence. On the second courtyard there is a stone path that now has been cemented. On the right and left of the path there is the tombs of Sunan Drajat lying irregularly.

Courtyard III is located higher than another two courtyards and is the most extensive courtyard. On courtyard III there is a wall on the southern side that serves as wall 
a

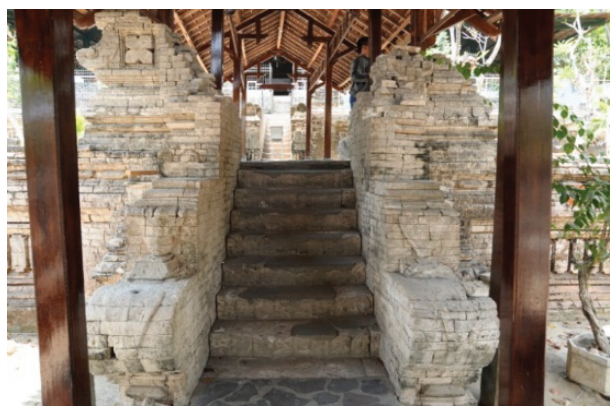

b

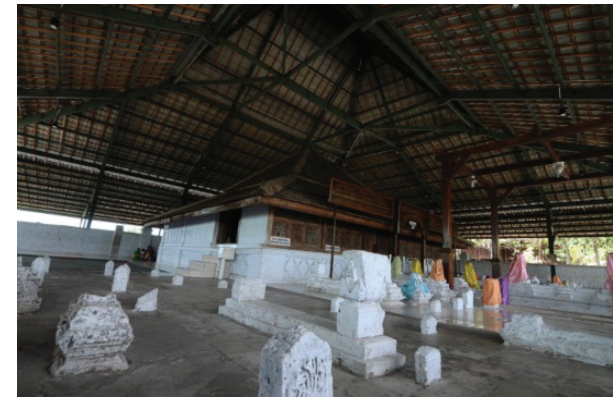

Figure 4: (a) Gapura Courtyard II of Sunan Drajat tombs, (b) Complex III courtyard of Sunan Drajat tombs (Photo: Windu Karsa).

cupola that has a butterfly-shaped entrances to fight. In front of the entrance gate of Susa there with high steps. On courtyard III there are two pieces of the cupola.

Cupola I is located in southern courtyard III with a rectangular floor plan of the pyramid's roof. South side walls serve as building cupola I courtyard III. At the entrance, there is a stone wall and archway courtyard III. At the western and eastern walls of the cupola I there is the entrance to the right and left side of the cupola. In cupola I there are 14 graves of Sunan Drajat relatives.

Cupola II is located in the north cupola I with a sketch of the square and roofed by joglo bulding with elevated floor. Cupola-shaped wall is gebyok engraved with floral motives, carvings also found on the door of the cupola on the south side. On the cupola there are two rooms called room A and room B. Room A located in this part of the south and contains six pieces of the tombs of the son of Sunan Drajat. The room is located on north part of room B with a raised floor. In the room, there is the tombs of Sunan Drajat (next to the Barata) and his wife (on eastern part).

\section{Tourist Behaviors and the Damage of Sunan Giri and Drajat Tombs}

\subsection{Tourist behaviors}

Generally, activities undertaken by pilgrims in Sunan Giri and Sunan Drajat tombs, among others: 


\subsubsection{Grave pilgrimage}

Ritual grave pilgrimage is done sitting around the grave of Sunon then greeting the guardian led by cleric or religious scholars. Reading surah Al-Fatihah and salowat of Prophet Muhammad, praying to wali, and closed with dhikr and wirid. The pilgrimage activity can be done at any time ( $24 \mathrm{~h}$ ). However, there is confidence the day and month are considered good for the pilgrimage, i.e. Friday and months of Shaban and Muharram. Pilgrims also often visited the tombs on weekend or during school holidays.

\subsubsection{Salat}

Other activities undertaken by the pilgrims are praying especially when pilgrims visiting during prayer times. Not a few pilgrims who visited before dawn, so they began to make pilgrimages after fojr prayers.

\subsubsection{Iktikaf}

Activities of iktikaf is a series of worship in Ramadan. Iktikaf is silence in the mosque, especially in the evening the last 10 days of fasting. In other Woli Songo tombs, this activity not quite popular because mostly very little pilgrims who came at Ramadhan month.

\subsubsection{Ritual tradition event}

Some ritual tradition practiced in the tombs complex of Sunan Giri, among others, Haul (the anniversary of the death) of Sunan Giri every $24^{\text {th }}$ of Rabi'ulawwal, and rituals of religious ceremonies of Islam such as the Moulud Nabi (the birthday of the Prophet Muhammad), Isra Miraj, and Revelation of the Quran. While in Sunan Drajat, ritual traditions among others is Houl of Sunan Drajat.

Sunan Drajat complex also features a museum that was built by the department of Tourism and Culture Lamongan. The Pilgrims usually also took time to get into the museum that contains information about degrees and repository history of Sunan Giri relics. Number of visitors to the museum are relatively few compared with the number of pilgrims. This means that not all visitors will enter the museum tombs. Actually, in the compound of Sunan Giri also been completed museum but when the research is done, not yet ready to open to the public. 
The duration of pilgrimage activity by each pilgrims or the group of pilgrims may be different. Some body or group only do pilgrimage on $15 \mathrm{~min}$, there are also pilgrims who done it for an $1 \mathrm{~h}$. It depends on the density of their individual schedules. If entourage of pilgrims use travel agents and has a series of pilgrimage destinations the the pilgrimage will be adapted.

Great waves of pilgrims, mainly often done by groups have an impact on the tombs in the Wali Songo tombs complex. Some of the pilgrims are not realize that their behavior threatens the sustainability of the tombs complex as a heritage area. Behavior that often done by pilgrims are: put the slippers on the tombs, lean on a tombstone, sat their children on top of the headstone, and let their children being on the tombs. Such behaviors were done in the tombs complex of Sunan Giri and Sunan Drajat also in the tombs of other Wali Songo.

a.

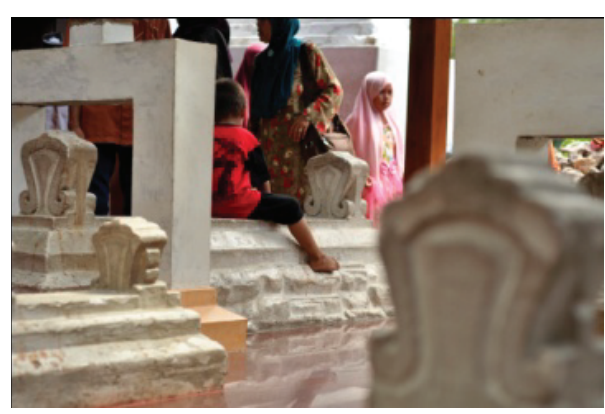

b.

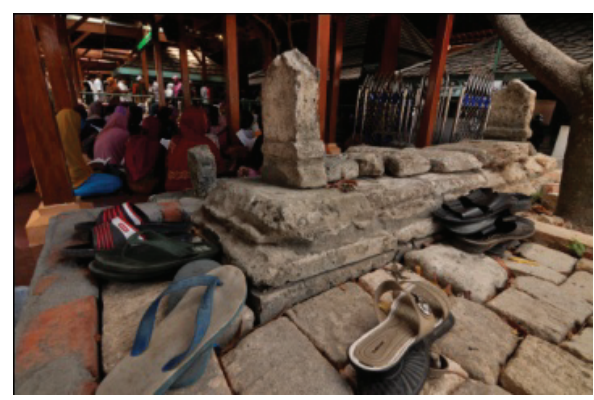

Figure 5: (a) A son let to sit above the tombs, (b) Slippers put around the tombs (Photo: Windu Karsa).

\subsection{Damage identification}

Based on observations made in the tombs complex of Sunan Giri and Sunan Drajat, it is known that some damage was found in the tombs of Sunan Giri and Sunan Muria are:

\subsubsection{Tombs complex of Sunan Giri}


TABLE 1: Damage identification on Sunan Giri Tombs Complex.

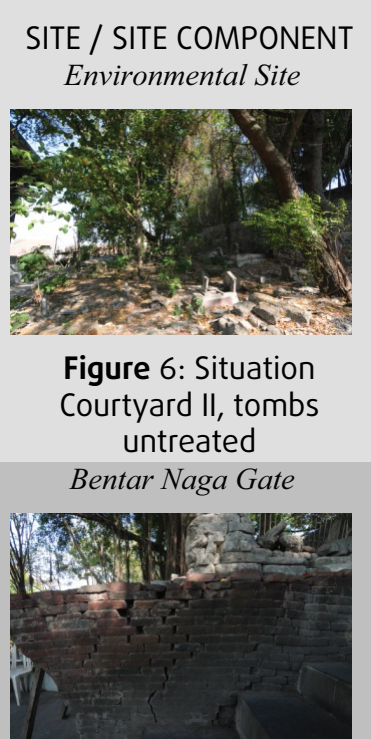

Figure 7: Conditions wear and cracks on the Bentar gate Bentar II Gate

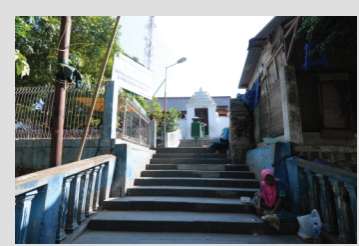

Figure 8: Bentar gate remains one piece

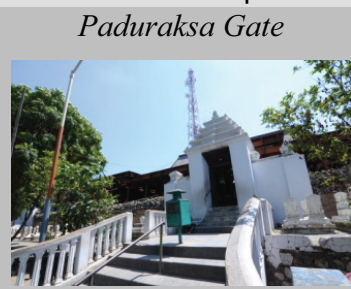

Figure 9: Paduraksa Gate on courtyard III

Fence on courtyard III

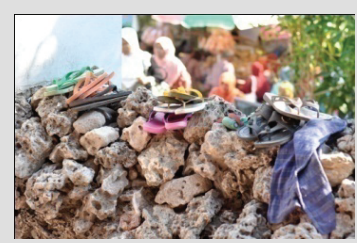

Figure 10: Fences tombs utilized a place to put

\footnotetext{
footwear
}

\section{CURRENT DAMAGES}

THREAT CAUSE

EFFECT

Environmental sites are well maintained but some parts in I and II courtyards are not organized and a lot of garbage

It occurs very high level of damage and very high level of cracks. There are a lot of scratches and streaks

Weather, the tiny plants, human vandalism, lack of intensive restoration efforts

No cleanup efforts, indiscriminate waste Environment site is disposal by visitors/ not well ordered pilgrims.
Threatened severe damage and destruction of the components of the site
Damage on the gate Bentar 1 piece for the construction of a new fence. Gate extant condition as well as high wear
Vandalism, development policy is a new fence

\section{Damage and wear} occurs on the steps of the gate paduraksa. There is the threat of BTS Tower which is

Activities visitors, policy installation BTS Tower located beside the grave
Fences made of coral stone is not treated properly and were threatened
Visitor activity, the absence of good restoration efforts
Damaged and

ened broken extinction of site components 


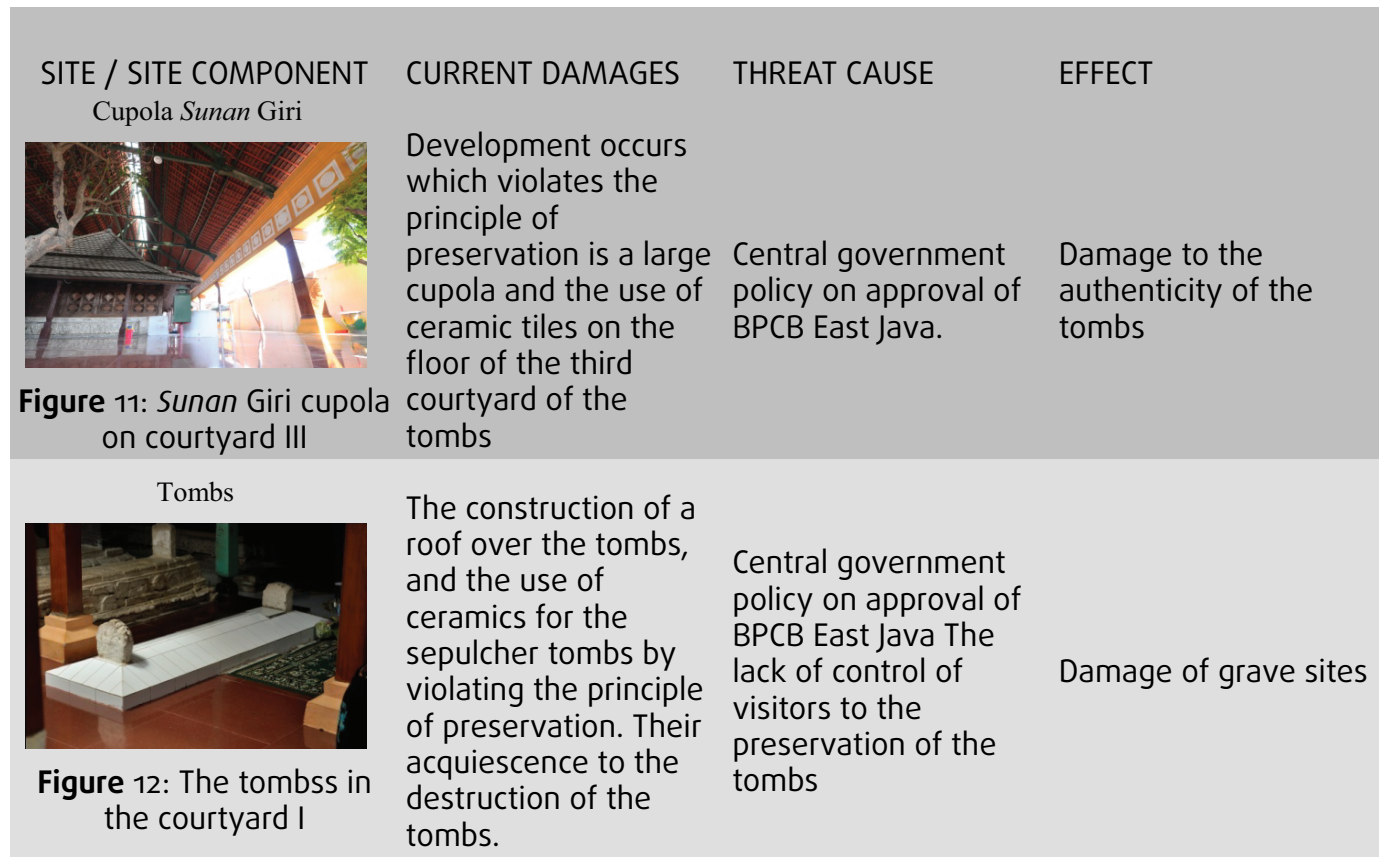

\subsubsection{Tombs complex of Sunan Drajat}

TABle 2: Damage identification on Sunan Giri Tombs Complex.

\begin{tabular}{|c|c|c|c|}
\hline $\begin{array}{c}\text { SITE / SITE COMPONENT } \\
\text { Environmental Site }\end{array}$ & CURRENT DAMAGES & THREAT CAUSE & EFFECT \\
\hline $\begin{array}{l}\text { Letriven } \\
\text { Figure } 13: \text { The front } \\
\text { courtyard of the Tombs }\end{array}$ & $\begin{array}{l}\text { In general, the } \\
\text { environment is quite } \\
\text { orderly, but some } \\
\text { components of the } \\
\text { fence looks unkempt }\end{array}$ & No restoration efforts & $\begin{array}{l}\text { Damaged and } \\
\text { destroyed }\end{array}$ \\
\hline $\begin{array}{c}\text { Figure 14: Gapura I } \\
\text { conditions and Fences }\end{array}$ & $\begin{array}{l}\text { The gate and fence in } \\
\text { a state of almost } \\
\text { damaged }\end{array}$ & $\begin{array}{l}\text { No maintenance and } \\
\text { restoration efforts }\end{array}$ & $\begin{array}{l}\text { Damaged and } \\
\text { destroyed }\end{array}$ \\
\hline $\begin{array}{c}\text { Figure 15: Gate of } \\
\text { Courtyard I Conditions }\end{array}$ & $\begin{array}{l}\text { Damaged condition } \\
\text { and not maintained at } \\
\text { the gate courtyard II }\end{array}$ & $\begin{array}{l}\text { No maintenance and } \\
\text { restoration efforts }\end{array}$ & $\begin{array}{l}\text { Damaged and } \\
\text { destroyed }\end{array}$ \\
\hline
\end{tabular}




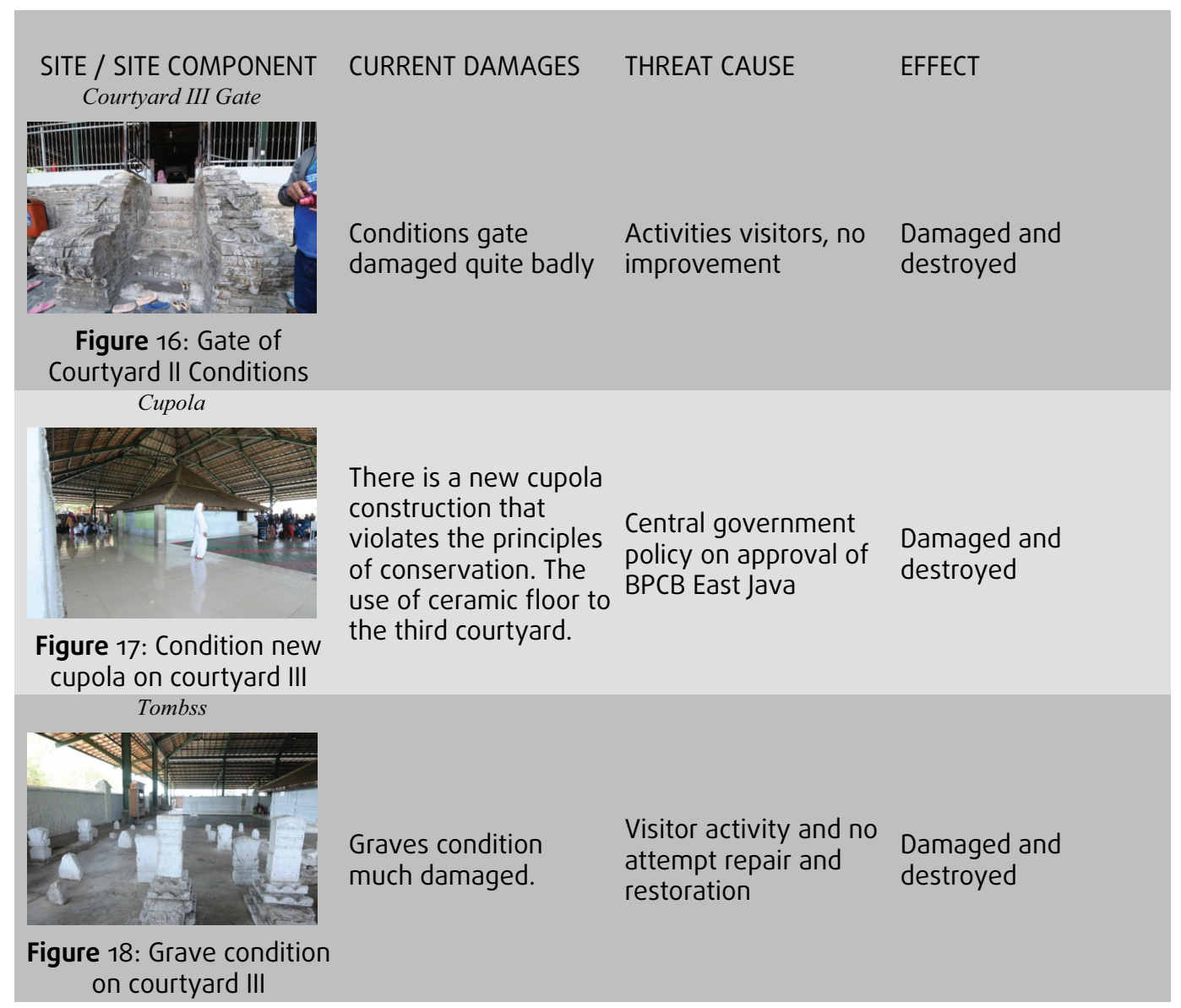

The Table 1 and Table 2 above illustrating the damages on the tombs complexes of Sunan Giri and Sunan Drajat. The damages are serious enough in most of the tombs complex. Both of the main gate and the subsequent gate which is a marker on both the tombs complex suffered serious damage and no restoration efforts, just visible efforts to prop the building with wood or iron that is temporary and not permanent. Besides the graves are located in the first and second courtyards, look unkempt or repairs broken until the new headstone replacement by using ceramics.

Activities of visitors is also the biggest cause of the damage to parts of the gate and tombs that were in the first on the second courtyard of the tombs complex. There are no strict controls over the activities of visitors. Visitors can perform various activities freely without rules like sitting against a headstone. Sitting on top of the headstone, especially by children and scrawling tombs. As explained on Table 1 row 1, 4, 5, 7 and Table 2 row 4, visitor activity caused the damages at the Sunan Giri on Courtyard II, Paduraksa Gate on courtyard III, fences tombs that utilized a place to put footwear, and the tombs in the courtyard I. While at the grave of Sunan Drajat, visitor activities caused the damage at courtyard III, especially in the gate and grave around main hall of Sunan Drajat tombs. 


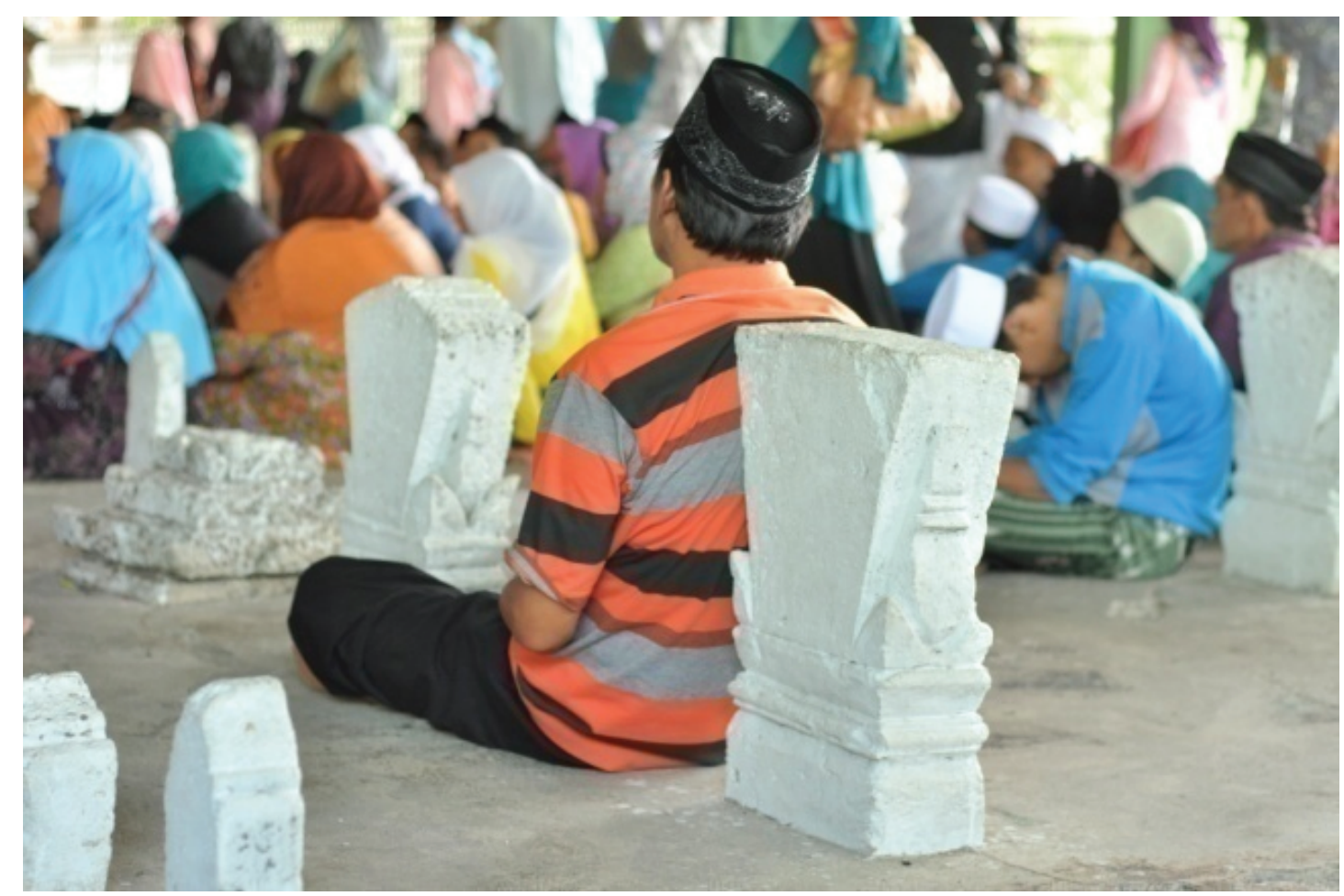

Figure 6: Activities visitors on courtyard of Sunan Drajat tombs (Photo: Windu Karsa)

The greatest damage is on the construction of a new roof that covers the main courtyard of the tombs complex as well as the replacement of the tile floor on the main courtyard in both the tombs. This violates the principles of preservation of cultural heritage, especially changing the original cultural heritage. Especially on the grave of Sunan Giri new development that ignores the principles of restoration and preservation is very dangerous because it occurs at the preservation of most of the tombs complex. It is unfortunate that the building has actually done by the central government and on leave by the BPCB that should be the primary responsibility of the vicissitudes of cultural heritage preservation.

\subsection{Areas management of Sunan Giri and Sunan Drajat tombs for the future}

As stated in Article 4 of Law No. 11 In 2010, the scope of the protection of cultural heritage includes preservation, development, and utilization of cultural heritage on land and in water [1]. The preservation in the process of management are integrated, known as the Cultural Resource Management (CRM). The concept of CRM was introduced by archaeologists in the 1970 with coverage assessment historic properties (objects/historic building that has been listed as a cultural heritage by the state), older 
properties that may have cultural value (objects/old building cultural value but has not recorded), historic properties that have cultural value beyond reviews their historicity (objects/historical buildings that have a high cultural value), native graves, shipwrecks, museum collections, historical document, religious sites, religious practice (religious ceremony), folklore, tradition, and other social institutions [21].

If referring to Fowler, Sunan Giri and Sunan Drajat tombs complexes become part of the heritage buildings located within a religious site in which the management is inseparable from the concept of Cultural Resource Management [21]. Likewise, if referring to the Law No. 11 Year 2010, the management of cultural heritage area consists of three things, as stated in the previous paragraph, i.e. the protection, development and utilization. This study elaborates on the management of cultural heritage from the perspective of Law No. 11 Year 2010.

\subsubsection{Protection}

\section{Saving}

The saving of cultural heritage under Law No. 112010 proved to be the obligation of all people not just the government that the representation of the state. The saving was conducted in order to: i) prevent damage caused by human factors and/or nature that result in changes in the authenticity and values attached to them and ii) to prevent the removal and transfer of ownership and/or control of the cultural heritage which is contrary to the provisions of the legislation [1]

The establishment of institutions that manage the heritage area as Sunan Giri and Sunan Drajat is a form of rescue undertaken by community groups. Sunan Giri Foundation consists of community groups from each hamlet and village of Giri, while Sunan Drajat Foundation comes from the element of family or descendants of Sunan Drajat. The foundation is then raised technical worker's hygiene, security, and other personnel needed in order to maintain the tombs complex, in addition to maintain interpreter appointed by the local Cultural Heritage Preservation Agency (BPCB), though it also drawn from the local community.

In terms of the saving, the situation is already quite ideal. Foundation manager grave of Sunan Giri and Sunan Drajat already implementing appropriate measures to save though not maximized, particularly against damage to the supporting main tombs as gates and tombs are located around the main tombs. Furthermore, the saving system from the activity of pilgrims and other threats need to be improved and warn pilgrims 
who perform activities that threaten the preservation of cultural heritage in Sunan Giri and Sunan Drajat.

\section{Securing}

Security as stated in Article 61 of Law carried out in order to preserve and prevent heritage from being lost, broken, and destroyed. Safeguard of heritage is the duty of the owner and/or parties that control. Security is done by interpreters maintain and/or special police (guard) is authorized to: i) patrolling in the area of cultural property in accordance with its jurisdiction; ii) checking the mail or documents relating to the development and utilization of cultural property; iii) receiving and making a report about the occurrence of criminal acts related to the cultural heritage and forward it to the relevant authorities in the field of culture, the Indonesian National Police, or other related agencies). Arrested the suspects is handed to the Indonesian National Police (Article 62) [1].

Security cultural heritage as referred to in Article 61 and 62 must pay attention to their use for social, educational, education, development of science, religion, culture and/or tourism. Security is done by providing a protective, store and / or place objects of cultural heritage in an area free from natural and human disturbances (Article 63) [1].

Foundation business Sunan Giri and Sunan Drajat already attempted security functions by making regulations that led to the security of cultural heritage sites such as the banned doodle wall and did not hesitate to reprimand pilgrims who do not obey the rules in the graveyard. However, because sometimes the daily officers are not significant (when observed in Sunan Giri there were only two guards, so also in Sunan Drajat, then control is not optimal), there are still many pilgrims who leaned to the site (tombstone), including a fence that was in the front of the tombs of Sunan Drajat.

Furthermore, it takes effort to secure more particularly where the guards are really watching and warned the pilgrims to follow the rules like littering, striking out strikethrough, holding, and leaning on the tombs which resulted in the destruction of part of the tombs.

\section{Zoning}

Based on Article 72, zoning is a system of defining the limits of the breadth and utilization of a site of cultural heritage [1]. Utilization of the zone of cultural heritage 
made for the purpose of recreational, educational, appreciative, and/or religion. Zoning system in article 73 regulated by division: i) a core zone, ii) a buffer zone, iii) the development zone, iv) support zone [1]

The zoning system is a system to control land use in the future. Thus, it can be regulated and controlled activities that will be carried out in zones that have been set. Besides the purpose of zoning is to avoid conflicts in land use, for example, conflict with the merchant associated with the location manager is allowed by the merchants. This is the case in the tombs of Sunan Giri. Although it has provided a special place in Zone III for traders, but there are still many traders who occupy the first zone that should be sterile from trading activities. For merchants, selling around the core area of the tombs would bring greater profits than the market bottom, near the exit.

Institute for Preservation of Cultural Heritage in East Java has not set the zoning for the site of this cultural heritage. Thus it is necessary zoning efforts which can generally be described as follows:

TABLE 3: Zoning concept of Sunan Giri and Drajat Tombs Complex.

\begin{tabular}{|c|c|}
\hline \multicolumn{2}{|r|}{ Sunan Giri Tombs Complex } \\
\hline Core Zone & $\begin{array}{l}\text { Sunan Giri tombs and other tombs at the highest courtyard and Masjid } \\
\text { Sunan Giri }\end{array}$ \\
\hline Buffer Zone & Tombs at the second level and the first level after the gate serpent \\
\hline Development Zone & $\begin{array}{l}\text { Area of stand/kiosk and parking area as well as the planned building as } \\
\text { a museum }\end{array}$ \\
\hline Supporting Zone & Large bus parking area \\
\hline \multicolumn{2}{|r|}{ Sunan Drajat Tombs Complex } \\
\hline Core Zone & Sunan Drajat and other tombs at the floor (the highest) \\
\hline Buffer Zone & Around the tombs at lower levels, after the front gate \\
\hline Development Zone & $\begin{array}{l}\text { Replica of Sunan Drajat mosque, museums, markets/ kiosks and bus } \\
\text { parking area }\end{array}$ \\
\hline Supporting Zone & Nothing \\
\hline
\end{tabular}

The zoning system which has existed at this time should be evaluated application in the field because it is often only considered is the core zone that ignores the zone buffer and development, even in some cases damage is massive due to the construction of the steel roof in Sunan Drajat and also a wooden roof at the Tombs Giri that incidentally is the core zone. 


\section{Maintenance}

Maintenance as stipulated in Article 76 which is carried out by taking care of cultural heritage in order to prevent and combat the damaging effects of natural and/or human actions [1]. Treatment is done with cleaning, preserving and repairing the damage by paying attention to the authenticity of the form, layout, style, material and/or technological heritage. To perform maintenance, and local governments can appoint or put caretaker to perform maintenance of cultural heritage.

Related to the maintenance, BPCB of East Java has been appointed the maintained to maintain cleanliness and security at both sites. However, because only two officers for the grave of Sunan Giri and one person to the grave of Sunan Drajat then the foundations of Sunan Giri and Sunan Drajat has appointed interpreters maintained from the surrounding community. Interpreters routinely maintained in charge of cleaning the site of cultural heritage and periodically sprayed anti termite sprays on a wooden cupola tombs, both Sunan Giri and Sunan Drajat.

Furthermore, The foundations of Sunan Giri and Drajat can also maintain a more lifted interpreter with special ability in terms of stone, how to care for the graves, and so forth. Maintenance effort is also expected from the BPCB have routine control to attempt to maintain that damage can be prevented damage before significant damage occurs.

\section{Restoration}

The restoration referred in Article 77 is the restoration of heritage buildings and structures of cultural heritage damaged done to restore the physical condition by repairing, strengthening and/or preserve it through the work of reconstruction, consolidation, rehabilitation, and restoration. The restoration should take into account: i) the authenticity of the material, shape, layout, style, and / or technological progress, ii) its original state with the rate of change as small as possible, iii) use of techniques, methods, and materials that are not destructive, and iv) the competence implementing in the field of restoration [1].

In another explanation, the restoration should allow for adjustments in the future by considering public safety and the safety of cultural heritage. The restoration of a potential negative impact on the social environment and the physical environment should be preceded by an environmental impact assessment in accordance with the laws and constitution. Restoration is mandatory to get permission from the government in this 
case the Cultural Heritage Preservation Agency (BPCB) or the local government in this case the Department of Culture and Tourism, according to the authority.

According to the interview, last restoration conducted in tombs complex of Sunan Drajat (before the restoration of 2015) is in 1994. That is, it has been long enough Sunan Drajat graveyard is not restored by regulatory authorities. Unfortunately, once it restored with a roof constructed of steel, pilgrims would damage some part of sites, particularly in the core zone. Similarly, Sunan Giri, although restoration efforts by adding support facilities continue to be made and more massive walk, but the restoration sizeable conducted by the Central Government in this case the Directorate General of Culture, Ministry of Education and Culture significantly also threatens the existence of cultural heritage sites under and damage to the aesthetics of the tombs of Sunan Giri as many poles, even some who stood on a headstone.

Restoration efforts should be the responsibility BPCB East Java. Furthermore, there should be a good mechanism between the parties BPCB East Java and Central Government and Local Governments so they are not walk alone by their own interests which ignore each second preservation of the grave sites.

\subsubsection{Development}

\section{Revitalization}

Revitalization of cultural heritage sites as stated in Article 80 must pay attention to layout, social function, and/or native cultural landscape based on the study [1]. Revitalization is done reorganize function space, cultural values, and the strengthening of information about cultural heritage. In Article 82 is described that revitalization should be able to benefit in order to improve the quality of life and maintaining local cultural characteristics [1]

The establish of Sunan Drajat Museum and development processes Sunan Giri Museum is expected to build the value of culture and information of the figure of Sunan Giri and Sunan Drajat to visitors. So that they have more scientific knowledge about the figure Sunan they pilgrim and not simply understanding just passed down from generation to generation through mythology that developed in the oral tradition. Museum becomes the proper tools in the effort to revitalize the values or teachings brought by the trustees. Sunan Drajat Museum already built in the complex of Sunan Drajat, can be designed and laid out better. Likewise, Museum Sunan Giri is in the 
process of arrangement, should be made as attractive as possible in order to attract people to learn more about their guardian figure that they came for pilgrim.

\section{Adaptation}

Adaptation as stated in article 83 is the effort to develop the heritage area in order to be able to meet the needs of today, while maintaining: i) characteristics of native and/or advance the heritage buildings, ii) characterizes the genuine cultural landscape and/or ground level cultural heritage sites or the heritage area prior to adaptation. Adaptation is done by: i) defending the values attached to the cultural heritage, ii) expanding its facilities in accordance with the requirements, iii) changing the arrangement of the space is limited, iv) maintaining the architectural style, the original construction, and the aesthetic harmony of the surrounding environment [1].

Construction of facilities supporting to tomb complex of Sunan Giri, such as foundation office of Sunan Giri, stairs leading to a core zone of the tombs, a parking lot under the arch typical of Gresik regency, and souvenir stalls also conducted in order to increase the comfort of visitors. But the construction of a wooden roof with poles that too much in the core zone seemed they were impressed to add full-page first because of the position and the number of poles is too much, thus reducing the space for the pilgrims and not pay attention to the concept of adaptation as described in this law. Also, in the complex of Sunan Drajat toilet facilities were also built in the northern part of the mosque is Masjid Sunan Drajat reconstruction and also parking in front gardens in order to improve the comfort of visitors. Nevertheless, the steel roof is built on the core zone, really has threatened the existence of the site, because in addition to the implementation of adaptation at all, in its development turned out to be devastated several parts of the cultural heritage sites located in the core zone.

\subsubsection{Utilization}

Pursuant to Article 72 paragraph (3), the use of the zone in the heritage can be done for the purpose of recreational, educational, appreciative, and/or religion [1].

\section{Religion}

Pilgrimage tombss of saints for the majority muslim community is a spiritual necessity. Therefore, it is not uncommon that people do a regular pilgrimage activities, either 

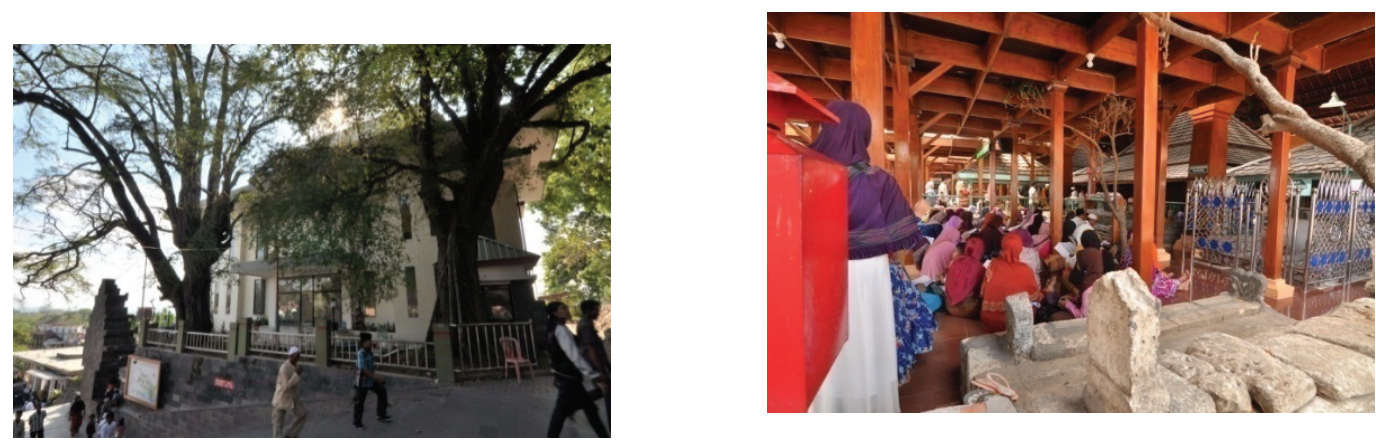

Figure 7: (a) Sunan Giri Museum still underconstruction, (b) Roof on core zone of Sunan Giri tombs (Photo: Windu Karsa)

yearly, half-yearly or monthly. The reason is strong enough that selected community activities of this pilgrimage is in order to seek (ngalap) blessings and miracles [22]. The concept of blessing and miracles owned trustee is not believed by the general muslim community. But for a community that holds the tradition of pilgrimage, the concept of blessings and miracles become important and become the main thrust of activity visiting the shrines of wali.

Religious understanding about grave pilgrimage which is believed by some muslim communities is encouraging big wave activity pilgrimage of the trustees, including Sunan Giri and Sunan Drajat. Interviews with the foundation of Sunan Giri Foundation officer said that on average, visitors to the tombs of Sunan Giri 4500 pilgrims per day. Because the number of visits the pilgrimage is very high, then in 1993 Sunan Giri Foundation founded in order to facilitate the activity of religious communities, especially the grave pilgrimage. Likewise with Sunan Drajat, although not as many as Sunan Giri because only achieve 4500 to 10000 pilgrims per month, in 1994 also established by Sunan Drajat Foundation.

\section{Tourism}

The legal basis which can be used for utilization of Sunan Giri and Sunan Drajat tombs complexes is Law No. 10 of 2009 on Tourism, This rule stated that tourist can enjoy the heritage of cultural heritage with regard to preservation [23]. So that, this tombs complex which is the cultural heritage can be used as a pilgrimage tour. Talking pilgrimage of wali tombs, it will discuss also about tourism activities. If explored, mostly pilgrimage activities carried out in bulk by a group of people, such as schools, 
prayer/tahlilan groups, villagers, or families. Almost certainly when it visits or pilgrimages that guardian executed en masse it will need a mode of transportation. Modes of transport which are used by the pilgrims was a big bus and micro bus.

Many travel agency that grew up in the cities where people have a tradition of wali pilgrimage, such as Surabaya, Jombang, Kediri, Malang, Lamongan, Tuban, Kudus, Jepara, and Demak. There is a relationship between pilgrimage tradition and the growth of travel agency in some areas. Travel agency that provide services deliver pilgrims to the wali's tombs of trustees have a variety of packages, including Pilgrimage Packages of five wali (exclude wali tombs that located in Central and West Java), Pilgrimage Packages of eight wali (exclude Sunan Gunung Jati tombs complex), Pilgrimage Packages nine wali, as well as Pilgrimage Packages wali 8 plus Yogyakarta. For Pilgrimage Package wali 9 rarely offered because of the travel time takes longer because of the need to Cirebon, the regency that Sunan Gunung Jati tombs located, and the prices were too high for the pilgrims who dominated the middle and lower class.

The problems that arise from the use of tourism is the number of tourists is very high with the average visit 2000 to 3000 visitors per day (interviews with the Sunan Giri Foundation officer) which resulted in the preservation of threatened both the tombs complex. Besides the absence of rating a good management, especially when they make a pilgrimage activity in the first page that there are many relics that need to keep and save. When the tourists arrive at the tombs complex is directly concentrated on the first page so that the accumulation of the tourists.

Serious efforts are needed to make the visitor management rules including attention to the carrying capacity of attraction given the status of cultural heritage so that it will not threaten the preservation of cultural heritage relics in the both of tombs complex. Utilization of cultural heritage for tourism purposes in the tombs complex also has positive economic impact to the surrounding community including increased pilgrimage packages by various travel agencies. Thus, the various interests can be accommodated without harming each other.

\section{Educational}

One of the benefits derived from the existence of cultural heritage by the act, is the use of education and science. The tombs complex of Sunan Giri and Drajat has been used for the purposes of education and science. Despite the relatively few high school and college students to visit for the purpose of assignment of schools and colleges. Based on interviews with administrators, students around Surabaya, Gresik, and Lamongan 
routinely conduct study visits while on pilgrimage at the tombs complex of Sunan Giri and Sunan Drajat. Some of the research produced by students as well as researchers from universities are also a lot to do in the tombs complex.

In the future, more efforts are needed to increase the use of educative for the pilgrims themselves. The existence of the museum complex in the tombs of Sunan Drajat not maximized to provide educational benefits of the cultural values of the character and architecture of the tombs building. Utilization museum is currently managed by the tourism department Lamongan but visible management is not maximized so unattractive to visitors. While in the tombs complex of Sunan Giri is still in the process of making the museum so it cannot be accessed.

\section{Conclusions}

Activities that tourists do (pilgrims) in Sunan Giri and Sunan Drajat tombs complexes are tombs pilgrim, salat, iktikaf, and attending special ritual event. The duration of tomb pilgrim activity by each pilgrim or a group of pilgrims is different. Some body or group only do pilgrimage on $15 \mathrm{~min}$, there is also $1 \mathrm{~h}$. It depends on the density of their individual schedules.

Pilgrims perform various activities such as sitting against a headstone, allow their children to sit on top of the headstone, touching old gate, and put their footwear on tombs. That pilgrims activities caused the damages at the Sunan Giri on Courtyard II, Paduraksa Gate on courtyard III, fences tombs that utilized a place to put footwear, and the tombss in the courtyard I. While at the grave of Sunan Drajat, visitor activities caused the damage at courtyard III, especially in the gate and grave around main hall of Sunan Drajat tombs.

The ideal cultural heritage management in Sunan Giri and Sunan Drajat for its sustainable according Law No. 11 Year 2010 is in three ways: i) protection: saving, securing, zoning, maintenance, restoration, ii) development: revitalization, adaptation, and iii) utilization: religion, tourism, education.

\section{Acknowledgements}

Special thanks to H. Ahmad Shobirin and H. M. Yahya, officer of Sunan Giri and Sunan Drajat Foundations. 


\section{References}

[1] Republik Indonesia. Undang-undang No 11, 24 November 2010, tentang cagar budaya [about cultural heritage], Jakarta 2010 [in Bahasa Indonesia] http://www . unesco.org/culture/natlaws/media/pdf/indonesie/ind_act11_ 10_clther_indorof

[2] Chambert-Loir H, Claude G. Ziarah dan wali di dunia Islam [Pilgrimage and the guardian of the Islamic world]. Komunitas Bambu, Depok; 2010. p. 1-472 [in Bahasa Indonesia] https://www.bukukomunitasbambu.com/toko/ ziarah-dan-wali-di-dunia-islam/

[3] Vijayanand S. Socio-economic impacts in pilgrimage tourism. International Journal of Multidisiplinary Research 2012; 2 (1): 329-343. https : //www. researchgate.net/ publication/265193250_SOCIO-ECONOMIC_IMPACTS_IN_PILGRIMAGE_TOURISM

[4] Ashfaq M, Parveen S. Socio economic impact of pilgrimage tourism: A geographical enquiry of Matavashino Devi. Journal of Scientific and Research Publication 2014; 4 (7): 1-6. https://www .academia.edu/9617813/Socio_Economic_Impact_ of_Pilgrimage_Tourism_A_Geographical_Enquiry_of_Matavashino_Devi

[5] Libison KB, Muraleedharan KP. Economic benefits of pilgrimage tourism: a case study of Sabarimala pilgrimage with special reference to Pandalam rural locality in Kerala (India). South Asian Journal of Tourism and Heritage 2008; 1 (1): 57-64. https://www.researchgate.net/publication/228310860_Economic_ Benefits_of_Pilgrimage_Tourism_A_Case_Study_of_Sabarimala_Pilgrimage_ with_Special_Reference_to_Pandalam_Rural_Locality_in_Kerala_India

[6] Gladstone DL. From pilgrimage to package tour: Travel and tourism in the third world. Routledge, New York; 2005. p. 1-235 https://books.google.co.id/books/about/From_Pilgrimage_to_Package_Tour .html?id=BRnxu1SRzowCEredir_esc=y

[7] Dick HW. The rise of a middle class and the changing concept of equity in Indonesia: An interpretation. Indonesia 1985; 39: 71-92. https://www.jstor.org/stable/ 3350987? seq=1\#page_scan_tab_contents

[8] Hefner RW. Islam, state, and civil society: ICMI and the struggle for the Indonesian middle class. Indonesia 1993; 56: 1-35. https://www. jstor.org/stable/3351197? seq=1\#page_scan_tab_contents

[9] Wardi IN. Pengelolaan warisan budaya berwawasan lingkungan: studi kasus pengelolaan living monument di Bali [Environmentally management of cultural heritage: A case study of living monument management in Bali]. Jurnal Bumi 
Lestari 2008; 8 (2): 193-204 [in Bahasa Indonesia]. https://www.researchgate. net/publication/242197627_PENGELOLAAN_WARISAN_BUDAYA_BERWAWASAN_ LINGKUNGAN_STUDI_KASUS_PENGELOLAAN_LIVING_MONUMENT_DI_BALI

[10] Sunarimahiningsih YT. Model pengelolaan cagar budaya berbasis partisipasi masyarakat sebagai upaya pelestarian cagar budaya [Cultural heritage management model based on community participation as an effort to preserve cultural heritage]. Seri Kajian Ilmiah 2011; 14 (11): 52 [in Bahasa Indonesia]. http://www . digilib.ui.ac.id/file?file=pdf/abstrak-134601.pdf

[11] Muttaqin LA. Model Pelestarian berdasarkan perundang-undangan: Studi kasus kawasan cagar budaya Kotagede Yogyakarta [Preservation model based on legislation: Case study of the cultural heritage region Kotagede Yogyakarta]. [Theses], Universitas Gadjah Mada, Yogyakarta; 2014. p. 1-146. [in Bahasa Indonesia] http://etd.repository.ugm.ac.id/index.php?act=view\&buku_id= 78448\&mod=penelitian_detail\&sub=PenelitianDetail\&typ=html

[12] Wuryani E, Purwiyastuti W. Pengelolaan objek wisata kawasan candi berbasis kearifan lokal [Tourism object management on temple areas based on local wisdom]. Jurnal Pariwisata Tourisma 2014; o (6): 1-14. http://ris.uksw.edu/ jurnal/read/kode/j00787

[13] Ichwan M. Pengelolaan sumberdaya arkeologi di kawasan Giri sebagai destinasi wisata religi [Archaeological resource management in Giri as a destination of religious tourism]. [Theses], Universitas Gadjah Mada, Yogyakarta; 2013. p. 1282. [in Bahasa Indonesia]. http://etd.repository.ugm.ac.id/index.php?mod= penelitian_detail\&sub=PenelitianDetail\&act=view\&typ=html\&buku_id=68309

[14] Schiffer MB. Toward a unified science of the cultural past. In: Research strategies in historical archaeology. South SA, (Eds). Academic Press, Albuquerque; 1977. p. 1340. https://uq.rl.talis. com/items/C7166303-6031-7FFE-413B-54F6FA49BCAB . html

[15] Shackley M. Managing sacred sites. Thomson, Padstow; 2001. p. 45-46. https://books.google.co.id/books/about/Managing_Sacred_Sites.html? id=F18-QxgyHIEC\&redir_esc=y

[16] McKercher B, du Cros H. Cultural tourism: The partnership between tourism and cultural heritage management. Haworth Hospitality Press, New York; 2002. p. 1-262. https://books.google.co.id/books/about/Cultural_Tourism.html?id= InVGWVCI9F4C\&redir_esc $=y$

[17] Pearson M, Sullivan S. Looking after heritage places: The basic planning for heritage for managers, landowners and administrators. Melbourne University 
Press, Melbourne; 1995. p. 1-384. https://books.google.co.id/books/about/ Looking_After_Heritage_Places.html?id=dLOgAAAAMAAJ\&redir_esc=y

[18] Earl J. Building conservation philosophy. Donhead, Shaftesbury; 2003. p. 1129. https://books.google.co.id/books/about/Building_Conservation_ Philosophy .html?id=7ipoAAAACAAJ\&redir_esc=y

[19] Santosa et al. Dinamika ruang wisata religi makam Sunan Giri di Kabupaten Gresik [The dynamics of religion tourism space of the tomb of Sunan Giri in Gresik Residence]. El Harokah Jurnal Budaya Islam; 2014. 16: 2. p. 176. http://ejournal. uin-malang.ac.id/index.php/infopub/article/view/2775

[20] Hartono T. Kompleks makam Sunan Prapen: Tinjauan terhadap latar belakang pendiriannya [Sunan Prapen tomb complex: a review of the background of its establishment]. [Theses] Universitas Gadjah Mada, Yogyakarta; 1990. p. 56. http: //digilib.fib.ugm.ac.id/book/detail/1101

[21] Fowler DD. Cultural resources management. In: Advances in archaeological method and theory. Springer; 1982. 5. p. 1-50 https://www. jstor.org/stable/i20210049

[22] Chaer MT. Ngalap barăkah dan karămah: Analisis makna ziarah di makam Mbah Priok, Koja Jakarta Utara [Expect blessings and miracles: The meaning analysis of the pilgrimage at the tomb of Mbah Priok, Koja North Jakarta]. Jurnal Muaddib 2014; 4 (1): 45-71. https://www. academia.edu/15602024/NGALAP_BAR $\{\%\} C 4\{\%\} 82 \mathrm{KAH}$

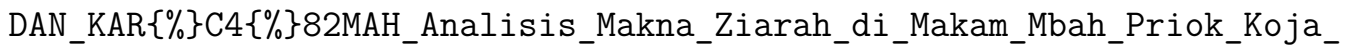
Jakarta_Utara_Jurnal_MUADDIB_Vol.04_No.01_Januari-Juli_2014_ISSN_ 2088-3390

[23] Republik Indonesia. Undang-undang No 10, 16 Januari 2009, tentang pariwisata [about tourism], Jakarta 2009 [in Bahasa Indonesia] http://www . kemenpar .go.id/ userfiles/file/4636_1364-UUTentangKepariwisataannet1.pdf 